\title{
ЕТНІЧНА МАРКОВАНІСТЬ ВЛАСНИХ НАЗВ У ТВОРЧОСТІ В. З. НЕСТАЙКА (НА МАТЕРІАЛІ ПОВІСТІ «ЧАРІВНІ ОКУЛЯРИ»)
}

Недогибченко М. М. Етнічна маркованість власних назв у творчості В. 3. Нестайка (на матеріалі повісті «Чарівні окуляри»).

У статті розглянуто типологію та основні функціональні особливості етнічно маркованих власних назв у повісті В. Нестайка «Чарівні окуляри». Проаналізовано можливості класифікації таких одиниць та 3'ясовано їх основне функціональне призначення у художньому творі, розрахованому на дитячу та юнацьку аудиторію.

Ключові слова: етнічно маркована одиниця, антропонім, онім, дитяча художня література.

Недогибченко М. Н. Этническая маркирование имен собственных в творчестве В. 3. Нестайко (на материале повести «Волшебные очки»).

В статье рассмотрена типология и основные функциональные особенности этнически маркированных имен собственных в повести В. Нестайко «Волшебные очки». Проанализирована возможность классификации данных единиц и установлено их основное функциональное предназначение в художественном произведении, рассчитанном на детскую и юношескую аудиторию.

Ключевые слова: этнически маркированная единица, антропоним, оним, детская литература.

Nedogibchenko M. M. Ethnical marking proper names in works by V. Z. Nestaiko (on the material of the story «The Magic Glasses»).

In the article, there were analyzed typology and major functional peculiarities of ethnically marked proper names in the story «The Magic Glasses» by V. Z. Nestaiko. Possibilities of classification for these items were explored and their main functions in the art literature piece aimed on secondary and high-school students were established.

Key words: ethnically marked item, anthroponim, art literature for children.

Художня література для дітей завжди посідала особливе місце серед чинників формування національної свідомості, усвідомлення етнічної належності. Через відповідно оформлене художнє слово дитина пізнає світ, формує власну систему цінностей, збагачує знання i розширює світогляд, а отже, літературний твір здатний з юних літ пробудити інтерес до рідної історії та традицій, спонукати до пізнання й усвідомлення національних особливостей рідного народу та самобутності його культури. Відтак науковий аналіз можливостей формування етнічної маркованості 
художнього тексту для дітей через мовні одиниці різних рівнів на сьогодні виступає актуальною проблемою лінгвістики.

Мета статті - розглянути типологію, особливості та функціональностильові характеристики етнічно маркованих власних найменувань у дитячій прозі. Об'єктом наукового аналізу окресленої проблеми обрано повість В. 3. Нестайка «Чарівні окуляри». 3 огляду на те, що власні найменування виступають важливим значущим компонентом будь-якого художнього твору, зокрема і творів для дітей, предметом аналізу стали власні назви різних типів, що характеризуються виразною етнічною маркованістю.

Всеволод Зіновійович Нестайко вже кілька десятиліть віддано працює на ниві літературної творчості для маленьких і юних читачів. Сьогодні його доробок представлений розмаїттям казок та повістей різної тематики, проте всі вони характеризуються захоплюючим сюжетом, яскравими персонажами, світлим позитивним настроєм, веселим гумором, невловимою, але ефективною повчальністю та неповторним стилем майстра художнього слова, лауреата багатьох національних та міжнародних літературних премій. Однією $з$ характерних рис його ідіостилю $є$ активна та кропітка робота над словом: широкий діапазон мовних засобів завжди підпорядкований авторському задуму, кожне слово виконує певну функцію і $\epsilon$ важливим елементом формування як художньої цінності твору, так і його виразного потенціалу у формуванні багатого словникового запасу та засвоєння мовних норм дітьми через художнє слово.

Усі твори В. Нестайка засвідчують уважне ставлення автора до добору та створення власних назв. Особливо виразно це помітно в серії казок «Незвичайні пригоди в лісовій школі», що вже привертала увагу науковців в аспекті аналізу антропонімів. Ономастику літературних казок В. Нестайка досліджували А. Романченко, Н. Дейниченко, Л. Лиманчук, Т. Марченко. Науковці одностайні в позиції, що ономатворчість письменника є характерною прикметною рисою його індивідуального стилю, у наукових розвідках вони вказують на багатоплановість, багатовимірність, експресивність та інформативність як реальних, так i вигаданих автором антропонімів. Т. Марченко наголошує на тому, що письменник «вибудовує художньообразну систему своїх творів 3 урахуванням вікових психологічних особливостей читацької аудиторії», зокрема серед них виділяє «потребу у словотворчості і загострений інтерес до власних назв» [3, с. 347], які стимулюють автора до активної роботи над виразними та багатофункціональними антропонімами. Аналізуючи «промовисті» імена Нестайкових казкових персонажів, Н. Дейниченко і Л. Лиманчук зауважують, що письменник «продуктивно використовує експресивно-стилістичні можливості власних назв, які штучно створені творчою уявою письменника» [1, с. 84]. Цю думку підтримує i А. Романченко, зазначаючи, що «Всеволод Нестайко вдало використовує прийоми онімічної гри, передаючи юним читачам корисну () М. М. Недогибченко, 2013. 
інформацію про природу та історію» [5, с. 161]. Проте увага цих науковців була сконцентрована на творах для дітей дошкільного та молодшого шкільного віку. У нашій роботі увагу зосереджено на творі, розрахованому на старшу читацьку аудиторію. Повість «Чарівні окуляри», одна 3 найбільш сучасних робіт письменника, за жанром визначена як правдиво-фантастична повість, на сьогодні залишається актуальним об'єктом лінгвістичного дослідження.

Творчий доробок В. Нестайка загалом характеризується схильністю до активного залучення етнічно маркованих елементів у мовну канву художнього твору. Вони відіграють важливу роль у формуванні легкого сприйняття хронотопічного малюнку, дають змогу створити відповідний підтекст, що спонукатиме юних читачів до активного пізнання, збагачують як словниковий запас, так і знання дітей про історію та культуру рідного краю. Крім того, завдяки етнічно маркованим одиницям кожен твір автора набуває виразного національного колориту незалежно від подій, що описуються. Відтак вони є яскравою характеристикою авторського індивідуального стилю й ефективним інструментом позиціонування національної самобутності. Саме для дитячої літератури це набуває особливої ваги, адже в період дитинства і юності формується ставлення до національних цінностей, людина ідентифікує себе як представника певної нації, тому інформація, сприйнята через доступну та цікаву художню літературу, відповідну віковим особливостям читача, активно сприяє успішному протіканню цього процесу.

При з'ясуванні характерних рис функціонування етнічно маркованих елементів спираємося на визначення етнічного маркера, наведене у глосарії В. Свтуха: «Етнічний маркер (від нім. markieren - відмічати, ставити знак) - ознака, риса, характерна для особи чи то спільноти, пов'язана з їх походженням, що виокремлює особу або спільноту в етнічних мережах» [2, с. 48]. Як етнічно марковані ми визначали одиниці, що демонструють змістове чи формальне наповнення, здатне актуалізувати сприйняття відповідної одиниці як характерної для української мови та культури, зумовлює створення значеннєвого чи асоціативного поля властивих нації ознак. Однією з найбільш численних груп етнічно маркованих мовних одиниць у повісті «Чарівні окуляри» виявилася група власних назв.

У творах В. Нестайка, зокрема і в аналізованій повісті, власні назви вирізняються широким розмаїттям та високою частотністю вживання. Автор таким чином досягає відчуття конкретності та природності розгортання сюжету: він називає кожного персонажа, іноді даючи кілька варіацій його імені, постійно згадуються імена відомих історичних діячів, назви вулиць, станцій метро, визначних місць і будівель. Такий прийом позитивно впливає на якість сприйняття подій, наближає реципієнта до персонажів: читач сприймає не абстрактні картини, а цілком конкретизовані саме через постійну присутність власних назв як ключових елементів конкретизації.

Власні назви за своєю природою є одним з найбільш гнучких елементів, 
сприйнятливих до набуття етнічно маркованих характеристик. Одна 3 широко представлених груп - це імена людей. Вони репрезентовані різнотипними структурними моделями: одночленними - ім'я (Маргарита, Рудольфо, Грищько, Оксана), прізвище (Котляревський, Сетон-Томпсон, Андерсен); двочленними - ім'я та прізвище (Вася Богданещь, Ромка Черняк, Рита Скрипаль, Льоня Кучеренко, Джина Лолобриджида, Сильвестр Сталлоне, Арнольд Швариенегер), ім'я та по батькові (Ліна Митрофанівна, Юлія Юхимівна, Маргарита Степанівна); тричленними - прізвище, ім'я та по батькові (Ядвіга Станіславівна Ягодська, Анатолій Дмитрович Базилевич).

У використанні різних за структурою власних назв виразно виявляється етнічна маркованість. Так, для найменування персонажів автор добирає типові для України імена хлопчиків та дівчаток, причому майже не можливо знайти повні форми імен: використовуються поліфункціональні скорочення (Вася, Льоня, Ромка, Рита, Рудик), які одночасно є типовим репрезентантом мовної трансформації імен у дитячому середовищі спілкування, характеризують регіональні особливості антропоніміки, оскільки ці оніми сприймаються як типові українські найменування, а отже, їм властива змістова і формальна етнічна маркованість. Змістова сторона етнічних маркерів виражена через відбір типових для української етнічної спільноти антропонімів, а формальна маркованість реалізується через відповідні моделі скорочення повних антропонімів.

Окремим аспектом етнічної маркованості антропонімів виступає традиційне використання тієї чи тієї структури відповідно до соціальних ролей. Так, персонажі повісті називають однокласників здебільшого за двочленною онімною структурною моделлю «ім'я та прізвище», причому ім'я в цій структурі виражене скороченою формою (Рита Скрипаль, Льоня Кучеренко). Це формула, що найбільш часто застосовується в антропонімічній ідентифікації однокласників серед українських школярів. Найближчі друзі називають один одного тільки на ім'я або прізвисько, рідше - на прізвище, і такий відбір форми найменування є типовим для українців. Звертання до вчителів традиційно відбувається через використання двочленної структури «ім'я та по батькові» (Ліна Митрофанівна, Юлія Юхимівна), так само, як і в разі спілкування школярів з персонажами старшими за віком та статусом (Маргарита Степанівна, Рудольф Андрійович). При цьому близьких родичів навіть набагато старших за віком персонажі згадують лише за іменем, але здебільшого з постійним використанням біля нього загальної назви, що характеризує відповідні зв'язки персонажів (дід Грищько, баба Оксана). Отже, автор повністю зберігає традиційну функціональність власних назв на позначення людини, ретельно добираючи найбільш природний відповідник для кожної окремої ситуації.

Крім змістової та функціональної, дібрані автором прізвища персонажів репрезентують і формальну, найчастіше - словотворчу етнічну маркованість.

(C) М. М. Недогибченко, 2013. 
Більшість прізвищ утворені за допомогою типових українських формул, 3 допомогою суфікса -к (о), або закінчуються на приголосний, збережені всі особливості відмінювання українських прізвищ, зокрема, відмінювання чоловічих прізвищ на -ко та приголосний, відсутність такого відмінювання в жіночих аналогічних прізвищах. Можна говорити про те, що через художній твір дитина багатократно сприймає зразки правильного вживання та відмінювання антропонімів, закріпленого в мовній системі протягом багатьох десятиліть чи навіть століть. Етнічно марковані одиниці в такому разі виконують не лише зображальну й ідентифікаційну функцію, стаючи ідентифікатором певного персонажа i/або опосередкованим елементом його характеристики, але й додатково формують у читача правильне сприйняття мовних норм, розвивають мовні навички нормативного вживання, формування та відмінювання українських прізвищ. Крім того, широко представлена група українських імен та прізвищ створює насичене тематичне поле, сприяючи засвоєнню онімних елементів національної ідентифікації.

Антропоніми представлені і підгрупою різноманітних прізвиськ: Ромка Брюнет, Циган і Свист, Рудий Африканський Їжачок, Алик Мармиза. Цей різновид власних назв відзначається виразною етнічною маркованістю, здебільшого змістовою. Прізвиська, на відміну від імен і прізвищ, завжди $\epsilon$ експресивними елементами відкритої чи прихованої характеристики персонажа. Так, головний персонаж отримав від свого друга прізвисько «Рудий Африканський Їжачок» насамперед через зовнішні ознаки: «Рудим Африканським Їжачком мене Ромка Черняк назвав, лідер нашого класу. Ми тоді Африку з географії проходили. А волосся в мене справді руде, як жар. I настовбурчене, як голки в їжачка» [4, с. 3]. За відповідним принципом і сам головний персонаж називає свого друга «Ромка Брюнет», виділяючи у прізвиську його основну зовнішню ознаку - колір волосся. Той самий принцип покладено і в добір зневажливо-насмішливого прізвиська, який персонажі дають своєму однокласнику-грубіянові, - «Алик Мармиза». Як відомо, добір ідентифікаторів за зовнішніми ознаками - один 3 ключових принципів утворення прізвищ та прізвиськ в українській мові, відповідно, аналізований твір повністю відбиває цю етнічну особливість.

Варто звернути увагу на групу антропонімів, сформовану іменами відомих осіб: письменників (Котляревський), художників (Анатолій Дмитрович Базилевич), спортсменів (Андрій Шевченко), співаків (Софія Ротару) тощо. За функціональним призначенням ця група лексем відрізняється від аналізованих раніше. Через ці оніми автор активно формує широке асоціативно-тематичне поле національної ідентифікації сприйняття подієвої канви. За допомогою цих одиниць письменник активно створює підтекст, надає художньому тексту багатовимірності та глибини, розширює світогляд читача, сприяючи таким чином його активному й пасивному сприйняттю національних традицій, історично-культурних фактів i персоналій. 
Прикметною рисою є типова для шкільного середовища мовна звичка дещо неформального називання письменників лише за прізвищами, опускаючи імена та по батькові, у той час як імена співаків та спортсменів сприймаються лише через формальну двочленну формулу, яка демонструє поєднання імені і прізвища. Отже, етнічна маркованість таких одиниць виявляється здебільшого на змістовому та функціональному рівнях.

За тим же принципом етнічний колорит репрезентований і одиницями, що належать до групи хрематонімів, - лексем, що об'єднують назви художніх творів та об'єктів культурної спадщини. Здебільшого ця група репрезентована через назви книжок («Кобзар», «Микола Джеря», «Лісова nicня», «Енеїда»). Актуалізуючи пізнавальний інтерес читача, вони водночас створюють виразне культурно-мистецьке, етнічно марковане тло. Через влучне та доречне застосування таких одиниць автор спонукає дитину дізнатися більше про культуру та історію власного народу.

Отже, аналіз найбільш широко представлених груп власних назв у повісті «Чарівні окуляри» продемонстрував високий ступінь насиченості твору етнічно маркованими власними назвами. Різні типи власних назв відрізняються за функціональним призначенням та змістом етнічно маркованих елементів. За допомогою таких одиниць письменник створює відповідний національний колорит, забезпечує активне опрацювання мовних норм, формує підтекст, сприяє виробленню навичок грамотного вживання і відмінювання цієї категорії слів, розширює світогляд дитини, розвиває відчуття національної самобутності та створює плідне підгрунтя для формування національної самоідентифікації юного читача. Усе це в комплексі дає змогу говорити про важливу роль етнічно маркованих мовних елементів - власних назв - у реалізації авторського задуму, у створенні відповідної експресивності і природності сприйняття художнього тексту для дітей. Цей напрямок дослідження потребує подальшої наукової розробки, що буде висвітлено в наших наступних роботах.

\section{Література}

1. Дейниченко Н. П. «Промовисті» імена Нестайкових персонажів Н. П. Дейниченко, Л. М. Лиманчук // Філологічні науки : синхронічний та діахронічний аспекти : зб. наук. праць ; за заг. ред. Л. М. Горболіс. - Суми, 2011. - С. 77-85.

2. Євтух В. Б. Етнічність. Глосарій / В. Б. Свтух - К.: Вид-во НПУ імені М. П. Драгоманова, 2009. - $170 \mathrm{c.}$

3. Марченко Т. Специфіка творення онімного простору літературної казки для молодшого шкільного віку (на матеріалі повісті-казки Всеволода Нестайка «Незвичайні пригоди в лісовій школі») / Т. Марченко // Вісник Львів. ун-ту : Серія філологічна. - 2012. - Вип. 56. - Частина 1. - С. 347-354.

4. Нестайко В. 3.Чарівні окуляри : правдиво-фантастична повість про надзвичайні пригоди київських школярів / В. 3. Нестайко - К. : Країна Мрій, 2012. - 192 с.

5. Романченко А. П. Ономастичний простір літературної казки Всеволода Нестайка / А. П. Романченко // Записки з ономастики : зб. наук. пр. / Одес. нац. ун-т ім. І. І. Мечникова ; [редкол. : О. Ю. Карпенко (відп. ред.) та ін.]. - Одеса : Астропринт - Вип. 14. - 2011. - С. 161-171.

() М. М. Недогибченко, 2013. 